\title{
Pay or Play Laws, ERISA Preemption, and Potential Lessons from Massachusetts
}

\author{
Amy B. Monahan
}

\section{INTRODUCTION}

States have for many years struggled to include employers in their health care reform efforts, in large part because the federal Employee Retirement Income Security Act of 1974 (ERISA) ${ }^{1}$ preempts any state law that relates to an employee benefit plan. ${ }^{2}$ While ERISA's preemption is undeniably broad, its exact contours remain difficult to discern. As a result, states continue to attempt creative ways to include employers in health care reform in ways that do not trigger ERISA preemption. The latest example of this creativity involves statelegislated economic incentives aimed at encouraging employers to participate in state health care reform efforts. These incentives are commonly referred to as "pay or play" laws. The idea is that employers can choose to "play" by providing health care to their workers according to state standards, or they can "pay" a monetary fee to the state in lieu of providing such coverage. While ERISA clearly preempts state laws that mandate employer-provided health coverage ${ }^{3}$ or dictate what services ${ }^{4}$ or to which employees coverage must be available, ${ }^{5}$ it is unclear whether

- Associate Professor of Law, University of Missouri-Columbia. I am grateful for comments received from participants in this symposium, participants in the University of Nebraska College of Law Faculty Colloquium, Elizabeth Weeks, and Larry Hansen, and for research assistance provided by Evan Fitts and Ben Hassebrock.

1. 29 U.S.C. $\S \S 1000-1461(2000)$.

2. See id. $\S 1144$ (a) (providing that "the provisions of this title ... shall supersede any and all state laws as they may now or hereafter relate to any employee benefit plan"). There is a significant exception for state laws regulating insurance, banking, or securities. Id. $\$ 1144(\mathrm{~b})(2)(\mathrm{A})$.

3. See, e.g., Dist. of Columbia v. Greater Wash. Bd. of Trade, 506 U.S. 125, 125 (1992) (preempting law requiring employers to provide health insurance coverage to those employees eligible for workers' compensation benefits).

4. See, e.g., Metro. Life Ins. Co. v. Massachusetts, 471 U.S. 724, 739 (state law mandating mental health benefits "falls within the reach of ERISA's pre-emption provision").

5. See, e.g., Air Transp. Ass'n v. City of San Francisco, 992 F. Supp. 1149, 1180 (N.D. Cal. 1998) (preempting law requiring certain employers to cover domestic partners on same terms as spouses). 
and under what circumstances pay or play laws will survive ERISA preemption.

Massachusetts, the most recent state to give pay or play laws a try, has adopted two such provisions (over the veto of Governor Romney) as part of its comprehensive health care reform legislation. ${ }^{6}$ The first provision is a "fair share employer contribution" that applies to employers with more than ten employees who fail to make a "fair and reasonable" contribution to employee health coverage. ${ }^{7}$ The amount of the fair share contribution is capped at $\$ 295$ per employee per year. ${ }^{8}$ Additionally, employers with more than ten employees are subject to a "free rider surcharge" if (1) the employer does not sponsor a cafeteria plan to allow employees to pay health insurance premiums on a pre-tax basis and (2) employees of the employer, or their dependents, access state-provided free care above certain threshold amounts. ${ }^{9}$ The fair share contribution went into effect on October 1, 2006, and is the first such pay or play provision to be implemented by any state. ${ }^{10}$ The free rider surcharge is scheduled to go into effect on July 1, 2007.11 These employer provisions are part of a comprehensive reform package that includes a mandate that all state residents purchase health insurance if an affordable policy is available to them, as well as individual and small group insurance market reforms. Together with the employer provisions, these reforms are aimed at dramatically increasing health insurance coverage in the state. ${ }^{12}$

While the Massachusetts fair share contribution is the first pay or play law to go into effect, several states have previously passed pay or play provisions. ${ }^{13}$ Most of these provisions were repealed before they

6. An Act Providing Access to Affordable, Quality, Accountable Health Care, ch. 58, 2006 Mass. Acts (forthcoming), available at http:/www.mass.gov/legis/laws/seslaw06/s1060058.htm [hereinafter Mass. Plan]. The legislation is designed to dramatically decrease the number of uninsured state residents, covering $95 \%$ of the currently uninsured within three years. PRESENTATION to THE JoINT CAUCUS FOR HOUSE MEMBERS, HEALTH CARE REFORM CONFERENCE COMMITTEE BlLL 2 (Apr. 3, 2006), http://www.mass.gov/legis/presentation.pdf. Many states, including California, have expressed interest in similar reforms. See, e.g., Jim Carlton, Schwarzenegger Embarks on Fight for Health Plan, WALL ST. J., Jan. 9, 2007, at A2 (analyzing California Governor Arnold Schwarzenegger's proposed plan to cover the uninsured).

7. Mass. Plan, supra note $6, \S 47$ (codified at MASS. GEN. LAwS ch. $149, \S 188$ ).

8. Id.

9. Id. $\S 44$ (codified at MASS. GEN. LAWS ch. $118 \mathrm{G} \S 18 \mathrm{~B}$ ).

10. Id. $\S 141$.

11. An Act Further Regulating Health Care Access, ch. 450, 2006 Mass. Acts (forthcoming), available at http://mass.gov/legis/laws/seslaws/sl060450.htm.

12. Stuart H. Altman \& Michael Doonan, Can Massachusetts Lead the Way In Health Care Reform?, 354 NEW ENG. J. MED. 2093, 2093 (2006).

13. See, e.g., MD. CODE ANN., LAB. \& EMPL. § 8.5-101-107 (West 2006); 1988 Mass. Legis. 
became effective. $^{14}$ To date, only one has been challenged in court, Maryland's Fair Share Health Care Fund Act. ${ }^{15}$ The Maryland Act would require employers with more than ten thousand employees in the state to either (1) spend an amount equal to $8 \%$ of their payroll on employee health care, or (2) pay to the state the difference between $8 \%$ of their payroll and their health care spending. ${ }^{16}$ In evaluating whether this pay or play law was preempted by ERISA, the district court had no trouble in determining that it was. ${ }^{17}$ On appeal, the Court of Appeals for the Fourth Circuit upheld the district court's decision, in a two to one split vote. $^{18}$

Despite the ruling on Maryland's Fair Share Act, Massachusetts's pay or play laws seem likely to survive a preemption challenge. Unlike Maryland's Act, which has a very strong "pay" provision, Massachusetts's fair share contribution law has a weak "pay" provision-arguably allowing it to survive an ERISA preemption challenge and be the first such law to do so. The free rider surcharge may similarly survive ERISA preemption on the basis that it involves only a premium-only cafeteria plan, which does not, by itself, relate to any ERISA plan.

This Article begins in Part II with a brief overview of ERISA preemption, and in Part III analyzes Retail Industry Leaders Association

Serv. 23 (West) (providing historical text of MASS. GEN. LAws ANN., ch. 118F); and 2003 Cal. Adv. Legis. Serv. 673 (Deering) (the California Health Insurance Act of 2003). Massachusetts first passed a pay or play law in 1998 , which would have required employers to pay a fee equal to $12 \%$ of payroll for full-time employees, with an offsetting credit against the fee for expenses incurred in providing health coverage for employees. MASS. GEN. LAWS ANN., ch. 151A, $\S 14 \mathrm{G}$ (b) (West 2006) (repealed 1996). It was repealed prior to implementation. 1996 Mass. Acts ch. $203, \S 4$. California's pay or play initiative, which was enacted by the legislature in 2003 , would have required employers to pay the state an amount equal to $80 \%$ of the cost of health insurance coverage for their employees, waiving the fee only if the employer-provided health insurance coverage, paid at least $80 \%$ of its cost, and the coverage met various requirements imposed by the state. $2003 \mathrm{Cal}$. Legis. Serv, 673 (West). California's law was repealed by voters in November 2004 before it took effect. See Jordan Rau et al., Election 2004 Healthcare Measures, L.A. TiMES, Nov. 4, 2004, at B1 (describing the rejection of Proposition 72 in the 2004 election). Pay or play laws are currently under consideration in many states. See NATIONAL CONFERENCE OF STATE LEGISLATURES, 20062007 Fair Share Health Care Fund or "PAY OR Play" Bills (2007), http:/www.ncsl. org/programs/health/payorplay2006.htm.

14. See supra note 13.

15. MD. CODE ANN., LAB \& EMPL. $\$ 8.5-101,8.5-107$ (West 2006). Other lawsuits against pay or play legislation are currently pending. See, e.g., Retail Indus. Leaders Ass'n v. Suffolk County, No. CV-06 531, 2005 WL 3782145 (E.D.N.Y. Feb. 7, 2005) (challenging the Suffolk County Program based on ERISA preemption); Golden Gate Restaurant Ass'n v. City of San Francisco, No. C066997 JSW, 2006 WL 3853281 (N.D. Cal. Nov. 8, 2006) (challenging the San Francisco program based on ERISA preemption).

16. MD. CODE ANN., LAB \& EMPL. § 8.5-102, 8.5-104 (West 2006).

17. Retail Indus. Leaders Ass'n. v. Fielder, 435 F. Supp. 2d 481, 493-98(D. Md. 2006)

18. Retail Indus. Leaders Ass'n v. Fielder, 475 F.3d 180, 198 (4th Cir. 2007). 
v. Fielder, the case holding Maryland's pay or play law preempted by ERISA. Part IV examines the Massachusetts fair share contribution, concluding that its weak pay or play law is not a disguised mandate and therefore is not likely to be preempted by ERISA. Part V turns to the free rider surcharge, concluding that it likely escapes preemption because compliance with the cafeteria plan requirement does not need to involve any ERISA plan. Finally, Part VI examines what the Massachusetts employer provisions are likely to contribute to health care reform and the lessons that other states may be able to learn from Massachusetts's efforts to involve employers in comprehensive health care reform.

\section{ERISA PREEMPTION GENERALLY}

This Section will provide a very brief overview of the evolution of ERISA preemption jurisprudence, a complicated subject on which the Supreme Court has ruled twenty times in the last thirty years, but which nevertheless remains murky. Section 514 of ERISA contains an explicit, and broad, preemption provision. It provides that ERISA generally preempts "any and all State laws insofar as they may now or hereafter relate to any employee benefit plan." 19 An employee benefit plan includes any employee pension benefit plan or employee welfare benefit plan. ${ }^{20}$ An employee pension benefit plan includes any plan, fund, or program which is established or maintained by an employer to the extent that such plan, fund, or program provides retirement income to employees. An employee welfare benefit plan includes any plan, fund, or program which is established or maintained by an employer to the extent such plan, fund, or program provides certain welfare benefits, including medical, surgical, or hospital care. ${ }^{21}$ Under these broad definitions, most employer-sponsored benefits are considered employee benefit plans under ERISA.

In an effort to better define the scope of preemption, the Supreme Court has held that a state law "'relates to' an employee benefit plan ... if it has a connection with or reference to such a plan.,"22 The subsections below will examine how the "reference to" and "connection with" standards have been interpreted by the Court.

\footnotetext{
19. 29 U.S.C. $\$ 1144(\mathrm{a})(2000)$.

20. Id. $\S 1002(3)$.

21. Id. $\S \S 1002(1),(2)(\mathrm{A})$

22. Shaw v. Delta Air Lines, lnc., 463 U.S. 85, 96-97 (1983) (citation omitted).
} 


\section{A. A "Reference to" an Employee Benefit Plan}

State laws are preempted by ERISA if the law has a reference to an employee benefit plan. ${ }^{23}$ A state law references an employee benefit plan if the law acts immediately and exclusively on such a plan, as did the law in Mackey $v$. Lanier Collection Agency \& Service, Inc. ${ }^{24}$ The relevant law in that case provided:

Funds or benefits of a pension, retirement, or employee benefit plan or program subject to the provisions of the federal Employee Retirement Income Security Act of 1974, as amended, shall not be subject to the process of garnishment ... unless such garnishment is based upon a judgment for alimony or for child support.

The law in that case applied only to ERISA plans and had an immediate effect on such plans. ${ }^{26}$ As a result, it was held preempted on the grounds that it contained an impermissible reference to an ERISA plan. ${ }^{27}$

Where a law does not act immediately and exclusively on ERISA plans, the Court has nonetheless found a "reference to" an ERISA plan where the existence of ERISA plans is essential to the law's operation. ${ }^{28}$ The two Supreme Court cases that involve the "essential to the operation" standard are District of Columbia v. Greater Washington Board of Trade ${ }^{29}$ and Ingersoll-Rand Co. v. McClendon. ${ }^{30}$ In Greater Washington Board of Trade, the existence of ERISA plans was essential to the operation of the law because the law required that benefits for injured employees be set by reference to the terms of existing ERISA plans. $^{31}$ In Ingersoll-Rand, the state law at issue provided employees with a wrongful discharge cause of action specifically when a principal reason for the termination was the employer's desire to avoid

23. $I d$.

24. 486 U.S. $825,829(1988)$.

25. Id. at $828 \mathrm{n} .2$ (quoting GA. CODE ANN. § 18-4-22.l (1982) (repealed 1990)).

26. Id. at 829-30.

27. Id at 830 .

28. Cal. Div. of Labor Standards Enforcement v. Dillingham Constr., N.A., Inc., 519 U.S. 316 , 325 (1997)

29. 506 U.S. 125 (1992).

30. 498 U.S. 133 (1990).

31. Greater Wash. Bd. of Trade, 506 U.S. at 130. The law in that case provided that "[a]ny employer who provides health insurance coverage for an employee shall provide health insurance coverage equivalent to the existing health insurance coverage of the employee while the employee receives or is eligible to receive workers' compensation benefits under this chapter." $I d$. at 128 (citing D.C. CODE ANN. § 36-307(a-1)(1) (LexisNexis Supp. 1992)). 
contributing to or paying benefits under the employer's pension plan. ${ }^{32}$ Under that law, the existence of an ERISA pension plan was a critical factor in establishing liability, and therefore essential to the law's operation. $^{33}$

The "reference to" standard, therefore, has limited application, preempting laws only where (1) "a State's law acts immediately and exclusively upon ERISA plans," or (2) "where the existence of ERISA plans is essential to the law's operation." ${ }^{34}$

\section{B. A "Connection with" an Employee Benefit Plan}

Even if a state law does not reference an ERISA plan, it may nevertheless be considered to "relate to" such a plan if it has a "connection with" such a plan. ${ }^{35}$ The leading case on the "connection with" standard, New York State Conference of Blue Cross \& Blue Shield Plans v. Travelers Insurance Co. ${ }^{36}$ concerned a state law that provided for hospital bill surcharges for patients whose insurance coverage was provided by a commercial insurer other than Blue Cross Blue Shield. ${ }^{37}$ The surcharge was equal to $24 \%$ of the bill. ${ }^{38}$ The Court emphasized that, in an area of traditional state regulation (such as health care) "the historic police powers of the States were not to be superseded by [federal law] unless that was the clear and manifest purpose of Congress." 39 Recognizing that the "relate to" language in section 514 of ERISA could apply to nearly any state law as "universally, relations stop nowhere," the Court declared that they "must go beyond the unhelpful text and the frustrating difficulty of defining its key term, and look instead to the objectives of the ERISA statute as a guide to the scope of the state law that Congress understood would survive." ${ }^{, 40}$ The Court then analyzed the

32. 498 U.S. at 140.

33. See id. (noting that "in order to prevail [under the state law], a plaintiff must plead, and the court must find, that an ERISA plan exists and the employer had a pension-defeating motive in terminating the employment").

34. Cal. Div. of Labor Standards Enforcement v. Dillingham Constr., N.A., Inc., 519 U.S. 316 , 325 (1997).

35. Shaw v. Delta Air Lines, Inc., 463 U.S. 85, 96-97 (1983).

36. 514 U.S. 645 (1995).

37. Id. at 649 .

38. Id. at 650. HMOs were similarly charged a surcharge on hospital bills that was variable, up to a maximum of " $9 \%$ of the aggregate monthly charges paid by an HMO for its members' in-patient hospital care." Id.

39. Id. at 655 (quoting Rice v. Santa Fe Elevator Corp., 331 U.S. 218, 230 (1947)).

40. Id. at 655-56 (internal citations omitted). Determining congressional intent is not necessarily easy, as some believe that Congress gave little thought to the scope of preemption when drafting ERISA, particularly as it applied to welfare plans. See Catherine L. Fisk, The Last Article 
history of ERISA and determined that "[ $\mathrm{t}]$ he basic thrust of the preemption clause ... was to avoid a multiplicity of regulation in order to permit the nationally uniform administration of employee benefit plans." 1

In analyzing the state law, the Court distinguished the hospital surcharge law from state laws that mandate employee benefit structures or their administration, which courts have consistently held to be preempted by ERISA. ${ }^{42}$ While the Court acknowledged that the New York state law made Blue Cross Blue Shield insurance attractive to ERISA health plans, it characterized the law's effect as having "an indirect economic effect on choices made by insurance buyers, including ERISA plans." ${ }^{, 43}$ The Court emphasized that an indirect economic influence did not "bind plan administrators to any particular choice." The Court quoted its previous pronouncement in Greater Washington Board of Trade that "[p]re-emption does not occur . . . if the state law has only a tenuous, remote, or peripheral connection with covered plans, as is the case with many laws of general applicability." ${ }^{, 45}$ The Court then went on to characterize the New York law as one of general health care regulation. ${ }^{46}$ It concluded that "cost uniformity was almost certainly not an object of pre-emption, just as laws with only an indirect economic effect on the relative costs of various health insurance packages in a given State are a far cry from those 'conflicting directives' from which Congress meant to insulate ERISA plans."47

Particularly important for our purposes is the Court's discussion of when an indirect economic incentive turns into a clearly preempted substantive mandate. The Court explained that "there might be a point at which an exorbitant tax leaving consumers with a Hobson's choice would be treated as imposing a substantive mandate." ${ }^{, 48}$ The Court found, however, that no showing had been made that the surcharges imposed by the New York law were "so prohibitive as to force all health insurance consumers to contract with" Blue Cross Blue Shield. ${ }^{49}$ In its

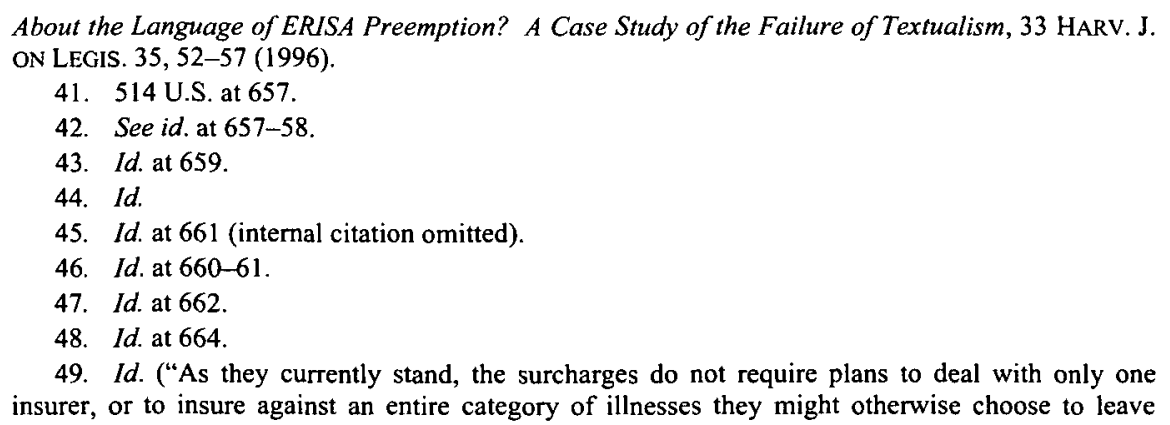


holding, the Court specified that "we do not hold today that ERISA preempts only direct regulation of ERISA plans" and acknowledged that "a state law might produce such acute, albeit indirect, economic effects, by intent or otherwise, as to force an ERISA plan to adopt a certain scheme of substantive coverage or effectively restrict its choice of insurers, and that such a state law might indeed be pre-empted under $\S 514 .{ }^{, 50}$ The New York surcharges, the Court held, do not force such choices and "affect only indirectly the relative prices of insurance policies." result, the Court found that the New York surcharges were not preempted by ERISA. ${ }^{52}$

In the years since Travelers, the Court has not strayed far from its analysis. While the Court has toyed with embracing an explicit conflict preemption standard, it has not done so. ${ }^{53}$ The "connection with" standard remains one of magnitude, focused on whether the law at issue interferes with ERISA's primary objectives. As the Court in Egelhoff $v$. Egelhoff summarized, "we look both to the objectives of the ERISA statute as a guide to the scope of the state law that Congress understood would survive, as well as to the nature of the effect of the state law on ERISA plans. ${ }^{\text {54 }}$ Benefit mandating statutes consistently have been held preempted under this test. ${ }^{55}$ State laws that intrude on core ERISA concerns, such as the primacy of plan documents, the payment of plan benefits, and the ability of an employer to provide a nationally uniform benefits package have also been preempted under this standard. ${ }^{56}$ Nevertheless, economic incentives that do not bind plan administrators to a particular choice have withstood preemption challenges. ${ }^{57}$

without coverage.").

50. Id. at 668 (emphasis added).

51. Id.

52. Id.

53. See Egelhoff v. Egelhoff, 532 U.S. 141, 152-53 (2001) (Scalia, J. and Ginsburg, J., concurring).

54. Id. at 147 (internal citations omitted).

55. See, e.g., Shaw v. Delta Air Lines, Inc., 463 U.S. 85,100 (1983) (holding that a state law was preempted given the "the plain language of $\S 514(\mathrm{a})$, the structure of the Act, and its legislative history").

56. See, e.g., Egelhoff, 532 U.S. at 146-50 (2001) (Scalia, J. and Ginsburg, J., concurring) (summarizing previous decisions).

57. See, e.g., Cal. Div. of Labor Standards Enforcement v. Dillingham Constr., N.A., Inc., 519 U.S. 316, 334 (1997) (holding that state "statute alters the incentives, but does not dictate . . . choices" and thus withstands ERISA preemption); N.Y. State Conf. of Blue Cross \& Blue Shield Plans v. Travelers Ins. Co., 514 U.S. 645, 668 (1995) (holding that state law that did not "effectively restrict ... choice of insurers" was not preempted by ERISA). 


\section{The Strong Pay or Play LaW-Maryland's Fair Share ACt}

In 2006, Maryland enacted the Fair Share Health Care Fund Act (hereinafter the "Maryland Act"), requiring employers with more than ten thousand employees in the state to either (1) contribute $8 \%$ of their payroll to employee health care or health insurance, or (2) pay to the state an amount equal to the difference between what the employer spends on employee health care and $8 \%$ of payroll. ${ }^{58}$ The law (which in practice would apply only to Wal-Mart), was promptly challenged by the Retail Industry Leaders Association (RILA). ${ }^{59}$

The challenge by RILA to the Maryland Act represented the first time a court has had the opportunity to rule on a state pay or play law. The district court held the Act preempted by ERISA under the "connection with" standard. ${ }^{60}$ In undertaking its analysis, the court examined "(1) 'the objectives of the ERISA statute as a guide to the scope of the state law that Congress understood would survive,' and (2) 'the nature of the effect of the state law on ERISA plans."

With respect to the first factor, the court stated that the main objective of ERISA was to permit nationally uniform benefit plan administration. $^{62}$ The court found that the Maryland Act would violate this objective by subjecting employers to a potentially great number of state, local, and municipal laws dictating health care spending, and would require employers to "segregate a separate pool of expenditures for its Maryland employees and structure its contributions-and employees' deductibles and co-pays-with an eye to how this will affect the Act's $8 \%$ spending requirement." 63

With respect to the second factor, the court found that the "intended effect" of the Act was to force Wal-Mart to spend at least $8 \%$ of total wages on health care, and therefore the second factor was "fully satisfied."64 The court found that Travelers offered the state no help in

58. MD. CODE ANN., LAB. \& EMPL. $\S \S 8.5-104(b), 8.5-101$ (d)(1) (West 2006).

59. Retail Indus. Leaders Ass'n v. Fielder, 435 F. Supp. 2d 481, 484 (D. Md. 2006), aff'd, 475 F.3d 180 (4th Cir. 2007). For a detailed analysis of the Maryland Act and ERISA preemption, see Edward A. Zelinsky, Maryland's "Wal-Mart" Act: Policy and Preemption, 28 CARDozo L. REv. $847,850-78$ (2006).

60. Retail Indus. Leaders Ass'n, 435 F. Supp. 2d at 494. Because the court held the Act preempted under the "connection with" standard, it did not analyze the Act under the "reference to" standard. Id.

61. Id. (quoting Egelhoff, 532 U.S. at 147).

62. Id.

63. Id. at 495 .

64. Id. 
overcoming preemption because there was no authority in that case to suggest that state statutes mandating that an employer provide a certain monetary level of welfare benefits in an ERISA plan should survive preemption. ${ }^{65}$

The court then analogized the Maryland law to a benefit mandating law, apparently based on the premise that, given the choice between spending $8 \%$ of payroll on employee health care or paying an equal amount of money to the state, "no rational employer would choose to pay the State." 66 The choice is characterized as a Hobson's choice and, as noted in Travelers, a Hobson's choice "'would be treated as imposing a substantive mandate.", 67

In a two to one decision, the Court of Appeals for the Fourth Circuit upheld the decision of the district court. ${ }^{68}$ The appellate court used very similar reasoning to the district court in coming to its conclusion that the Maryland Act was preempted by ERISA. The court began by emphasizing that the primary objective of ERISA was to provide a uniform regulatory regime over employee benefit plans, and that preemption is meant to protect ERISA plans from complying with conflicting directives of the states. ${ }^{69}$ With respect to the pay or play aspect of the law, the court stated bluntly that "[a] state law that directly regulates the structuring or administration of an ERISA plan is not saved by inclusion of a means for opting out of its requirements." ${ }^{70}$ The court seemed to temper this position when it later explained that "[e]ven if a state law provides a route by which ERISA plans can avoid the state law's requirements, taking that route might still be too disruptive of uniform plan administration to avoid preemption." 71

In evaluating the effect of the law, the Fourth Circuit agreed with the district court that no reasonable employer would pay the fee to the

65. Id.

66. Id. at 495,497 . One of the court's assumptions was that an amount equal to $8 \%$ of payroll could, in reality, only be spent in an ERISA plan. Id. at 497.

67. Id. at 497 (quoting N.Y. State Conference of Blue Cross \& Blue Shield Plans v. Travelers Ins. Co., 514 U.S. 645,664 (1995)).

68. Retail Indus. Leaders Ass'n v. Fielder, 475 F.3d 180, 183 (4th Cir. 2007)

69. Id. at 191 .

70. Id. at 192. The court cites Egelhoff in support of this position. In Egelhoff, employers could opt out of the state law at issue by including specific language in the plan document. Despite this "opt out," the Court held the law was preempted because the law mandated that plan administrators "either follow Washington's beneficiary designation scheme or alter the terms of their plan[s] so as to indicate that they will not follow it." Egelhoff v. Egelhoff, 532 U.S. 141, 150 (2001).

71. Retail Indus. Leaders Ass'n, 475 F.3d at 193. 
state. $^{72}$ Because the court found that the "only rational choice" was for employers to structure their ERISA plans to meet the minimum spending threshold, the Act was considered a benefit mandating law and therefore clearly preempted. ${ }^{73}$

In the end, the ruling on Maryland's law in large part turns on the effective lack of choice given to employers. Employers must either (1) spend at least $8 \%$ of payroll on providing health care to their employees, or (2) remit the difference between what they spend on health care and $8 \%$ of payroll to the State of Maryland. As both decisions point out, no rational employer would ever choose option number two. ${ }^{74}$ The connection with employee benefit plans is very strong-the Maryland Act essentially mandates that employers create an employee benefit plan and spend at least $8 \%$ of payroll on such a plan. The law therefore goes beyond the mere indirect economic incentive approved in Travelers and instead binds employers to certain choices, and infringes on an area of core ERISA concern - the national uniformity in benefit offerings.

While Maryland's strong pay or play law was preempted because of the effective mandate it put in place, the section below analyzes Massachusetts's fair share contribution pay or play law, which has a much weaker pay provision-potentially allowing the law to survive ERISA preemption.

\section{THE Weak Pay or Play LAW-Massachusetts's Fair SHaRe CONTRIBUTION}

The Massachusetts health care reform legislation contains two pay or play provisions that are potentially preempted by ERISA. The first, the fair share contribution (FSC), gives employers the option of playing by making a "fair and reasonable" contribution to employee health care or paying a fee to the state. ${ }^{75}$ The FSC applies to employers with more than ten employees who do not make a "fair and reasonable" contribution to employee health care coverage. ${ }^{76}$ An employer satisfies the "fair and reasonable" standard when it offers a group health plan and either (1) at least $25 \%$ of full time employees are enrolled in the plan and the

72. Id. at 197.

73. Id. at 193. The court also notes that this is the effect the Maryland General Assembly intended the Act to have, and that the fee creates an "irresistible incentive" to provide employees with a greater level of health insurance. Id. at 194.

74. Id. at 193; Retail Indus. Leaders Ass'n, 435 F. Supp. 2 d at 497.

75. See Mass. Plan, supra note $6, \S 47$.

76. Id. 
employer is making a contribution toward it, or (2) the employer offers to pay at least one third of the cost of coverage under the plan. ${ }^{77}$ The amount of the fee is capped at $\$ 295$ per employee, per year. ${ }^{78}$ Because of the modest-or weak-penalty associated with the fair share contribution, it will likely survive an ERISA preemption challenge because it is a mere indirect economic incentive for a plan administrator to make certain choices with respect to its health care plan.

\section{A. "Reference to"}

Under current ERISA jurisprudence, the FSC will be preempted if it either contains an impermissible reference to an ERISA plan or has an impermissible connection with such a plan. A state law contains an impermissible reference to an ERISA plan where it "acts immediately and exclusively upon ERISA plans ... or where the existence of ERISA plans is essential to the law's operation." 79 Under the first standard, the FSC does not appear to contain a reference to an ERISA plan. The FSC does not act immediately and exclusively upon ERISA plans because it applies to all employers, including those exempt from ERISA. ${ }^{80}$

A reference to an ERISA plan also does not appear to be found under the second standard. Unlike Greater Washington Board of Trade and Ingersoll-Rand, the Massachusetts FSC does not set benefits by reference to an ERISA plan, nor rely on the existence of ERISA plans in any way. Pursuant to the FSC law, an employer need not sponsor an ERISA plan, it can simply pay the designated fee. While an employer may be exempt from the FSC if it sponsors an ERISA plan meeting certain parameters, the law can easily operate and be enforced without the existence of any ERISA plans. Because the existence of an ERISA plan is not essential to the FSC's operation, the FSC should not be preempted under the "reference to" standard.

77. 114.5 MASS. CODE REgS. 16.03 (2006).

78. Mass. Plan, supra note $6, \S 47$. Approximately $8 \%$ of the 35,000 employers in Massachusetts with more than ten employees are expected to be affected by the fair share contribution. Massachusetts Proposes Minimum Standard for Employer-Based Care Under New Law, BNA Health CARE Daily ReP., July 5, 2006. The resulting revenue is estimated at \$26 million. Id.

79. Cal. Div. of Labor Standards Enforcement v. Dillingham Constr., N.A., Inc., 519 U.S. 316 , 325 (1997).

80. While most employers are subject to ERISA, government and church employers are generally exempt. 29 U.S.C. $\$ 1003$ (b) (2006). 


\section{B. "Connection with"}

The FSC does not appear to have an impermissible connection with an ERISA plan. To determine whether a law has an impermissible connection with an ERISA plan, we must examine (1) "'the objectives of the ERISA statute as a guide to the scope of the state law that Congress understood would survive," and (2) "the nature of the effect of the state law on ERISA plans."

It is well acknowledged that a primary purpose of ERISA was to permit the nationally uniform administration of employee benefit plans, and that preemption issues must be analyzed with that primary goal in mind. The FSC does raise issues concerning the nationally uniform administration of employee benefit plans. In order to be exempt from the FSC, employers must meet the coverage or contribution requirements imposed by the Massachusetts Division of Health Care Financing and Policy. That is, they must either cover $25 \%$ of full-time workers and contribute toward the coverage, ${ }^{82}$ or pay one third of the cost of coverage under the employer plan. For a national employer to be exempt from the fee, it would potentially need to alter its benefit administration in Massachusetts. The question is whether the small size of the FSC effectively eliminates the concern. While the Fourth Circuit in RILA held that the Maryland Act violated a fundamental purpose of ERISA by preventing nationally uniform benefit administration, this holding appears to be based on the court's conclusion that the law functioned as a mandate due to the "irresistible incentive" given to employers to spend $8 \%$ of payroll in their ERISA plans. ${ }^{83}$ Unlike the Maryland Act, the size of the FSC does not appear to force an employer's decision.

Instead of forcing an employer's decision, the FSC simply provides a small financial incentive for employers to comply with the FSC standards. Employers may elect to (1) sponsor a health plan that either covers $25 \%$ of its workers or for which they pay one third of the premium, or (2) pay a $\$ 295$ fee per employee per year to the state. ${ }^{84}$ What makes this law an interesting contrast to Maryland's Fair Share Act is that under the Massachusetts law it would, in almost all instances, be rational to elect option two. ${ }^{85}$ That is, to the extent the contribution

81. Egelhoff v. Egelhoff, 532 U.S. 141, 147 (2001) (citing Cal. Div. of Labor Standards Enforcement, 519 U.S. at 325).

82. MASS. CODE REG. 16.03.

83. Retail Indus. Leaders Ass'n v. Fielder, 475 F.3d 180, 193 (4th Cir. 2007).

84. See supra text accompanying notes 75-78.

85. Assuming no other costs or benefits, the $\$ 295$ per employee fee would in most cases be less 
provides incentives, it provides them to pay the FSC rather than adopt or amend an ERISA plan. On this view, the FSC does not require an employer to either adopt or amend an ERISA plan as the Maryland law does.

The FSC, then, looks more like an indirect economic incentive of the type at issue in Travelers. ${ }^{86}$ In Travelers, the effect of the New York state law was to make Blue Cross Blue Shield insurance economically more attractive than any other funding mechanism for ERISA health plans (as well as for any other hospital expense payor) ${ }^{87}$ The incentive was not insignificant, with a surcharge for non-Blue Cross Blue Shield payors of up to $24 \%{ }^{88}$ Nonetheless, the Court found that a generally applicable law in an area of traditional state regulation was not preempted by ERISA where it did not dictate choices or mandate benefits. ${ }^{89}$ The FSC appears to have a similar effect. It changes (slightly) an employer's incentives regarding health plan choices-in this case whether to offer a plan and whether to structure it to meet the $25 \%$ coverage or $33 \%$ contribution standard. As such, under a Travelers analysis, the FSC likely will not be seen as unduly interfering with the objectives of ERISA concerning nationally uniform benefit administration. It is clear, for example, that a state law requiring ERISA plans to use Blue Cross Blue Shield to finance benefits would be preempted by ERISA as interfering with nationally uniform benefit administration. Similarly, if Massachusetts required all employers to either cover $25 \%$ of their full-time employees or pay $33 \%$ of employee health insurance premiums, such a law would be preempted. But it seems that both survive preemption if there is a relatively modest financial disincentive associated with making different choices.

expensive than either covering $25 \%$ of employees under an employer plan and "contributing to" coverage or paying $33 \%$ of the premium for coverage under an employer plan, given that in 2005 the average premium for employer-based coverage in Massachusetts was reported to be $\$ 8,280$ per employee. See MassINC, Commonwealth Agenda 2006: Health Care, COMMONwEALTH: ONLINE EXCLUSIVES 2 (2006), http://www.massinc.org/fileadmin/online_exclusives/agenda_2006/health care.pdf (citing the 2005 National Survey of Employer-Sponsored Health Plans conducted by Mercer Human Resources Consulting). This is consistent with testimony that the purpose of the FSC was not to mandate employer coverage, but rather to make non-providing employers share some of the costs associated with uninsured state residents that are currently bome by employers who do provide health insurance coverage to their workers. See Michael Widmer, President of Mass. Found., Testimony in Support of Determination of Employer Fair Share Contribution (Aug. 8, 2006), http://www.masstaxpayers.org/data/pdf/bulletins/employ 1.pdf (discussing rationale behind FSC fee).

86. N.Y. State Conf. of Blue Cross \& Blue Shield Plans v. Travelers Ins. Co., 514 U.S. 645 (1995).

87. Id. at 659 .

88. Id. at 650 .

89. Id. at 668 . 
One concern the RILA court noted was the potential for a multiplicity of pay or play regulation. ${ }^{90}$ When considering strong pay or play laws, one could imagine a large multi-state employer having to potentially play under numerous state, local, and city laws. The effect of multiple weak pay or play laws on a multi-state employer, however, would be quite different. Multiple weak pay or play laws would simply involve the administrative inconvenience of checking the employer's plan against any requirements of the law and paying a small fee if necessary. Strong pay or play laws would actually require changes to the employer's ERISA plan in each of the jurisdictions. That type of compulsion is what ERISA preemption was trying to prevent. ${ }^{91}$ It is unlikely that ERISA was meant to preempt the imposition of small fees of the type present in the Massachusetts law. ${ }^{92}$ Again an analogy can be made to Travelers. The type of law at issue in Travelers-a hospital surcharge law that provided indirect economic incentives to ERISA plans to make certain choices in how to fund their plans-could be enacted in multiple jurisdictions and not be preempted. A multi-state employer would have to keep track of, and weigh, whether or not to make changes to its ERISA plan in each jurisdiction to take advantage of the incentives, or whether to accept the increased cost of making different choices. The Supreme Court in Travelers did not let concerns about this type of multiplicity of regulation affect its analysis, ${ }^{93}$ nor does it appear likely that such concerns would affect the preemption analysis of weak pay or play laws.

The RILA court, however, stated that "a state law that directly regulates the structuring or administration of an ERISA plan is not saved by inclusion of a means for opting out of its requirements."94 District courts in both the First and the Ninth Circuit have made similar rulings in cases involving city ordinances requiring entities choosing to do business with the city to offer benefits to domestic partners on the same terms as spouses. ${ }^{95}$ In $R I L A$ and the domestic partner cases, however, the laws at

90. Retail Indus. Leaders Ass'n v. Fielder, 475 F.3d 180, 194 (4th Cir. 2007).

91. Id.

92. See Travelers, 514 U.S. at 661-62 ("In sum, cost uniformity was almost certainly not an object of pre-emption.").

93. Id.

94. Retail Indus. Leaders Ass 'n, 475 F.3d at 192.

95. See Catholic Charities of Maine, Inc. v. City of Portland, 304 F. Supp. 2d 77, 92-93 (D. Me. 2004) (holding that health benefit domestic partners non-discrimination requirements are preempted by ERISA); Air Transp. Ass'n v. City of San Francisco, 992 F. Supp. 1149, 1180 (N.D. Cal. 1998) (same). 
issue have been found to leave the employer with no effective choice but to modify its ERISA plans. ${ }^{96}$

In Air Transport Association of America v. City of San Francisco, ${ }^{97}$ the air transport industry challenged a San Francisco ordinance that prohibited the city from entering into contracts with any entity that did not provide employee benefits on an equal basis to domestic partners as compared to spouses. ${ }^{98}$ The court held that, as applied to airport contracts, the ordinance was largely preempted by ERISA. ${ }^{99}$ In its preemption analysis, the court easily found a "connection with" an ERISA plan upon examining whether the purpose and effect of the ordinance interfered with Congress's objectives in enacting ERISA. ${ }^{100}$ It found that the ordinance's purpose was to require contractors to modify discriminatory employee benefit plans, and that the effect of the law would be the same. ${ }^{101}$ In addressing the City's Travelers-based "indirect economic effect" argument, ${ }^{102}$ the court asked whether the ordinance escaped preemption because it applied only to those companies with which the City does business. ${ }^{103}$ The court suggested that such an outcome would occur only where "the City wields no more power than an ordinary consumer in its contracting relationships."104 The City, the court found, exerted more economic power at the airport than an ordinary consumer would, due to the City's monopoly position as the airport

96. As discussed below, only RILA and Air Transportation Ass' $n$ are explicit in their "effective mandate" analysis. See discussion infra notes 97-115 and accompanying text (describing how each court found a mandate in the statute, even though the statute purported to offer an option). Two other cases, Catholic Charities and Council of New York v. Bloomberg, 846 N.E.2d 433 (N.Y. 2006), similarly ruled on city ordinances that required employers who did business with the city to provide benefits to the domestic partners of employees on the same basis that such benefits were provided to spouses. Both held the city ordinances to be preempted by ERISA. Catholic Charities, 304 F. Supp. 2d at 92-93; Council of New York, 846 N.E.2d at 441. Neither decision, however, provides much guidance that is useful to our pay or play analysis. In Catholic Charities, the court simply states that "none of the Supreme Court cases suggests that a state law is saved from preemption just because its mandate is conditional." 304 F. Supp. at 92. In Council of New York, the court held the law preempted on the basis that the law is "exactly what ERISA, as interpreted in Shaw, prohibits-to prescribe the terms of benefit plans." Council of New York, 846 N.E.2d at 441 . The court then dismissed the city's argument for a market participant exception to ERISA preemption, finding that the city in this case was acting as a regulator, not a proprietor, when it used "its bargaining leverage as a means of attaining policy ends." Id. In neither case does the court engage the Travelers-based argument regarding indirect economic incentives.

97. 992 F. Supp. 1149 (N.D. Cal. 1998).

98. Id. at 1155 .

99. Id. at 1180 .

100. Id. at 1176 .

101. Id.

102. Id. at 1167

103. Id. at 1176

104. Id. at 1180 . 
proprietor. $^{105}$ It was on this basis that the court found that the ordinance was "largely preempted by ERISA when applied to airport contracts." 106 This holding can be reconciled with the statement in Travelers that an economic influence can be so substantial as to function as a mandate and create a Hobson's choice. ${ }^{107}$ While this is not explicit in the Air Transport opinion, the court's argument is essentially that the City's monopoly position as airport proprietor results in airlines having no choice but to do business with the City, and, therefore, no choice but to modify their employee benefit plans in accordance with the ordinance. The fact that the ordinance only applied to employers who chose to enter into contracts with the City did not save it from preemption.

The appellate decision in RILA used very similar reasoning. The court stated that the fact that the law is optional does not save it from preemption, but it also found that the law involves a Hobson's choice, leaving a rational employer with no choice but to modify its ERISA plan. ${ }^{108}$ As Travelers tells us, where there is no effective choice, the law mandates benefits and is preempted by ERISA. ${ }^{109}$ Essentially, the RILA court found that spending $8 \%$ of payroll costs on an ERISA plan was not optional. Because there is a genuine choice associated with the Massachusetts FSC, a choice that was not present in either RILA or Air Transport, the FSC should not be preempted.

The RILA court cited Egelhoff in support of its position that the fact that a law is optional does not save it from preemption. ${ }^{110}$ In Egelhoff, the state law at issue, which governed beneficiary designations following a divorce, operated essentially as a default. ${ }^{111}$ The law did not apply if the plan sponsor included specific language in the plan document. ${ }^{12}$ The choices in Egelhoff were then to (1) comply with a law that was in direct conflict with ERISA, or (2) amend your ERISA plan to avoid the law's application. ${ }^{113}$ Each choice, individually, would be preempted by ERISA. The first option, complying with the state law, the Court easily found preempted as conflicting with a fundamental concern of ERISA-

105. Id.

106. Id.

107. N.Y. State Conf. of Blue Cross \& Blue Shield Plans v. Travelers Ins. Co., 514 U.S. 645, 664 (1995).

108. Retail Indus. Leaders Ass'n v. Fielder, 475 F.3d 180, 197 (4th Cir. 2007).

109. N.Y. State Conf. of Blue Cross \& Blue Shield Plans v. Travelers Ins. Co., 514 U.S. 645, 664 (1995).

110. Retail Indus. Leaders Ass' $n, 475$ F.3d at 182.

111. Egelhoff v. Egelhoff, 532 U.S. 141, 150 (2001).

112. Id

113. Id. 
paying plan benefits in accordance with plan documents. ${ }^{114}$ The second choice would also be preempted by ERISA because it would require plan administrators to modify their ERISA plans. ${ }^{115}$ As a result, regardless of the choice, the law related to an ERISA plan. This is not the case with the choices given to employers under the Massachusetts FSC. While requiring an employer to cover a certain percentage of employees or pay a certain percentage of employee premiums would clearly be preempted by ERISA as a benefit mandating law, the second choice is to pay a modest monetary fee to the state. The fee in no way implicates an ERISA plan. It does not relate to an employee benefit plan and should not be preempted. Rather, the FSC involves an indirect economic incentive to make certain choices regarding ERISA plans, but does not dictate such choices. Under Travelers, the FSC should not be preempted by ERISA.

\section{The Cafeteria Plan Pay or Play law-Massachusetts's FREE RIDER SURCHARGE}

The second Massachusetts pay or play law, the free rider surcharge (FRS), applies to employers with more than ten employees who do not "contribute to or arrange for" employee health coverage if employees access free state health care above a certain threshold. ${ }^{116}$ The amount of the surcharge varies from $10 \%$ to $100 \%$ of the state's cost, based on the number of incidents of free care in the past year, the number of employees, and "the proportion of employees for whom the ... employer provides health insurance."117 While the penalty can be steep, the FRS can be avoided by merely offering employees the ability to pay for health insurance on a pre-tax basis through a cafeteria plan. ${ }^{118}$ While the nature of the penalty suggests that Massachusetts was interested in requiring employers to actually pay for their employees' health care, the fact that an employer is exempt from the surcharge merely for offering a premium-only cafeteria plan suggests that what the FRS really is meant

114. Id. at 147.

115. Id. at 151 .

116. Mass. Plan, supra note $6, \S \S 32,44$. Whether the free rider surcharge applies will be set forth in regulations and is based on factors such as how many times a single employee of the employer accesses free care. Id. $\S 44$. Even if the employee utilization thresholds have been met, however, the free rider surcharge is only triggered once the state has expended $\$ 50,000$ or more in providing care to the employer's employees. $I d$.

117. $I d$.

118. Id. $\S 32$ (defining non-providing employer). 
to accomplish is making health insurance more affordable for individuals.

It is understandable why Massachusetts included this requirement in its health reform legislation. Under current law, employees are only able to pay for health insurance on a pre-tax basis if it is purchased through their employer and their employer offers premium payment through a cafeteria plan. ${ }^{119}$ If an individual buys coverage on the individual market, the premiums are only deductible if the individual is selfemployed. ${ }^{120}$ For most individuals, the ability to pay health insurance premiums on a pre-tax basis provides a very significant cost savings, making coverage more affordable and, in turn, making an individual more likely to acquire health insurance. ${ }^{121}$

A cafeteria plan is a plan established pursuant to section 125 of the Internal Revenue Code, which allows participants to elect to receive cash or some combination of qualified benefits. ${ }^{122}$ One of the qualified benefits that may be offered under a cafeteria plan is employer-provided health insurance. ${ }^{123}$ A premium-only cafeteria plan is, as the name implies, a cafeteria plan where the only benefit that is offered is the ability to pay insurance premiums on a pre-tax basis. A premium-only cafeteria plan is not, by itself, considered an employee benefit plan governed by ERISA. ${ }^{124}$ When an employer allows the pre-tax payments of ERISA health plan premiums through a cafeteria plan, however, the cafeteria plan is considered a funding mechanism of the ERISA plan and

119. Under $\S 106$ of the Internal Revenue Code of 1986 , employer contributions to coverage under an accident or health plan are excluded from an employee's gross income. I.R.C. $\S 106$ (2000). A premium-only cafeteria plan allows employees to make an election to reduce their cash compensation by the amount of their health insurance premiums. In turn, the employer pays the premiums on behalf of the employee. Because the contributions are now considered employer contributions under $\S 106$, they are exempt from the employee's income and are effectively paid on a pre-tax basis. Utilizing a cafeteria plan is the only means by which to make an employee's contributions toward health insurance excludable from income. President Bush has recently proposed amending the tax treatment of health insurance so that all individuals can deduct up to a certain amount of health insurance premiums from their taxable income, eliminating the preferential treatment provided to employer-provided coverage. See WHITE HOUSE NAT'L ECON. COUNCIL, REFORMING HEALTH CARE FOR THE 21 ST CENTURY 6 (2006), available at http:/www.whitehouse. gov/stateoftheunion/2006/healthcare/healthcare booklet.pdf ("Premiums for HSA-compatible insurance would be deductible ... when purchased on the individual market.").

120. I.R.C. $\S 162(l)(1)(B)(2000)$.

121. For a detailed examination of the effect of the pre-tax payment of health insurance premiums, see Paul Fronstin, Issue Brief No. 294: The Tax Treatment of Health Insurance and Employment-Based Health Benefits, EMP. BENEFIT RES. INST., June 2006, available at http://www. ebri.org/publications/ib/index.cfm? fa=ibDisp\&content_id=3642.

122. I.R.C. $\$ 125(\mathrm{~d})$.

123. I.R.C. $\S \S 125(f), 106(a)$.

124. Dep't of Labor Op. Ltr. 96-12A (July 17, 1996). 
therefore a part of such a plan. ${ }^{125}$ The extent to which a premium-only cafeteria plan constitutes part of an ERISA plan, then, turns on whether the premiums are paid to an ERISA plan or whether they are used to pay premiums on a health insurance policy not governed by ERISA.

In determining whether the health benefits funded by a premiumonly cafeteria plan constitute an ERISA plan, the involvement of the employer is key. As stated previously, an employee welfare benefit plan is a plan, fund, or program established or maintained by an employer to the extent the plan, fund, or program provides certain specified benefits, including medical benefits. ${ }^{26}$ For our current purposes, the phrase "established or maintained by an employer" is critical. It is possible that an employer could make health insurance available to employees but its involvement not rise to the level of employer sponsorship. In such a case, the health insurance would not be considered a plan subject to ERISA. A safe harbor contained in Department of Labor regulations provides that an employer will not be considered to have established or maintained an ERISA plan when it makes available to employees a group or group-type insurance program offered by an insurer, under which:

(1) No contributions are made by an employer or employee organization; (2) Participation [in] the program is completely voluntary for employees or members; (3) The sole functions of the employer . . . with respect to the program are, without endorsing the program, to permit the insurer to publicize the program to employees or members, to collect premiums through payroll deductions or dues checkoffs and to remit them to the insurer; and (4) The employer . . . receives no consideration in the form of cash or otherwise in connection with the program, other than reasonable compensation, excluding any profit, for administrative services actually rendered in connection with payroll deductions or dues checkoffs.

In determining whether an employer has endorsed a program under the third factor, one must examine whether the employer's actions would lead an employee to reasonably conclude that the employer did more than merely facilitate the program's availability. ${ }^{128}$ For example, where

125. Id.

126. 29 U.S.C. $\S 1002(1)(2000)$.

127. 29 C.F.R. $\S 2510.3-1(j)$ (2006)

128. Johnson v. Watts Regulator Co., 63 F.3d 1129, 1135 (5th Cir. 1995) (“[A]n employer will be said to have endorsed a program within the purview of the Secretary's safe harbor regulation if, in light of all the surrounding facts and circumstances, an objectively reasonable employee would conclude on the basis of the employer's actions that the employer had not merely facilitated the program's availability but had exercised control over it or made it appear to be part and parcel of the 
an employer is responsible for plan design or determining employee eligibility for coverage, courts have found the employer's role rises beyond merely making the program available to employees. ${ }^{129}$

No court has addressed the specific issue of whether an employer can make a group insurance program available to employees through a cafeteria plan but still fall under the safe harbor excluding the program from the definition of an ERISA plan. ${ }^{130}$ The use of a cafeteria plan to allow the pre-tax payment of premiums, however, does not appear to necessarily result in an insurance arrangement being considered an ERISA plan. ${ }^{131}$ It is not obvious that a cafeteria plan functions as

company's own benefit package."); see also Dep't of Labor Op. Ltr. 94-24A (July 1, 1994).

129. See, e.g., Butero v. Royal Maccabees Life Ins. Co., 174 F.3d 1207, 1213-14 (11th cir. 1999) (finding the safe harbor barred where the employer picked the insurer, decided on key terms such as portability and the amount of coverage, deemed some employees ineligible to participate, incorporated the policy terms into the plan description for its cafeteria plan, and retained power to alter compensation reduction for tax purposes).

130. While some courts have found group insurance arrangements made available through cafeteria plans do not qualify for the safe harbor excluding such plans from ERISA coverage, none of the holdings turned on the utilization of a cafeteria plan. See id. (finding the cafeteria plan at issue did not fall under the safe harbor provision because of the employer's actions, not because of the cafeteria plan's structure).

131. Several decisions do take into account the tax treatment of premium payments in determining whether the employer has made a contribution to the insurance arrangement. However, these cases examine the tax treatment of contributions to determine whether the amounts are employer or employee contributions. See, e.g., B-T Dissolution, Inc. v. Provident Life \& Acc. Ins. Co., 175 F. Supp. 978, 985 (2001) ("[E]xamining the tax consequences of the premium payments helps reveal who really 'paid' them."). However, some courts have found that merely enabling premium payments to be made on a pre-tax basis constitutes an "employer contribution" for purposes of the safe harbor. See Brown v. Paul Revere Life Ins. Co., No. CIV.A. 01-1931, 2002 WL 1019021 , at $* 7$ (E.D. Pa. 2002) (stating that the employer contributed to the policy by "enabling payments from pre-tax income" and by providing a premium discount). In the context of a cafeteria plan, it seems illogical to suggest that allowing pre-tax payment of premiums results in an employer contribution, as section 125 is intended to allow such pre-tax contributions from an employee's salary. In determining the source of the funds for cafeteria plan contributions, pre-tax salary contributions clearly come from the employee rather than the employer. In this respect, the court in Schwartz v. Provident Life \& Accident Ins. Co., 280 F. Supp. 2d 937, 941 (D. Ariz. 2003), appears to have the more persuasive analysis, stating, "[t]he dispositive question is whether [the employer] actually absorbed any portion of the cost of those premiums." In the case of a cafeteria plan, the employer has absorbed no such cost, despite the fact that such amounts are not included in the employee's taxable income. There are also cases which suggest that providing employees with a benefit they cannot receive as individuals, such as a group purchase discount, is sufficient to fail the safe harbor requirements, either because it is considered an employer contribution or because it is evidence of employer endorsement. See, e.g., Brown v. Paul Revere Life Ins. Co., 2002 WL 1019021, at *7; Stenger v. Provident Life \& Accident Ins. Co., 121 F. Supp. 1238 (E.D. Wisc. 2000). However, these cases rely on language in Treasury regulations concerning the definition of a group health plan [for purposes of COBRA] to reach their conclusion, reliance that seems misplaced in this context. Several courts have held that a group purchase discount does not negate the Department of Labor safe harbor for group insurance purchasing arrangements. See, e.g., Schwartz, 280 F. Supp. 2d at 939; Rubin v. Guardian Life Ins. Co., 174 F. Supp. 2d 1111, 1118-19 (D. Or. 2001). 
anything more than a payroll deduction, and no court has suggested otherwise. However, an employer would need to be knowledgeable of the ERISA safe harbor and take steps to ensure that its conduct did not rise to the level of endorsement of the program. Where the benefit is included in a cafeteria plan that offers multiple benefits, this would require careful communication on the employer's part. ${ }^{132}$ Nonetheless, it appears that an employer could offer a premium-only cafeteria plan to permit employees to pay for insurance coverage that is not part of an ERISA plan. This conclusion is critical for the ERISA preemption analysis that follows.

\section{A. The "Reference to" Standard}

As detailed previously, a state law is preempted where it "acts immediately and exclusively upon ERISA plans ... or where the existence of [ERISA] plans is essential to [the law's] operation."133 The FRS seems to easily escape preemption under this standard. As explained above, it is possible to have a premium-only cafeteria plan that is not considered part of an ERISA plan, ${ }^{134}$ and, for the same reason, ERISA plans are not essential to the law's operation.

\section{B. The "Connection with" Standard}

In order to determine whether a law has an impermissible connection with an ERISA plan we must examine (1) "the objectives of the ERISA statute as a guide to the scope of the state law that Congress understood would survive," "135 and (2) "the nature of the effect of the state law on ERISA plans. $" 136$

132. For example, the benefit that is intended to be covered by the safe harbor should not appear to employees to be part of the same package as other ERISA-covered benefit plans. The employer should not draft summaries for the ERISA-exempt plan that appear identical to its other benefit plan summaries, nor should the forms that are used for the ERISA-exempt plan be the same as other forms used for the employer's ERISA plans. The employer should make clear in its communication that it does not "sponsor" the ERISA-exempt plan, and that its sole function is to facilitate payroll deductions through the cafeteria plan to pay for the required premiums.

133. Cal. Div. of Labor Standards Enforcement v. Dillingham Constr., N.A., Inc., 519 U.S. 316, 325 (1997).

134. See supra Part II (discussing ERISA preemption generally); but cf. William G. Schiffbauer, ERISA Preempts Provisions of Massachusetts 'Play or Pay' Health Care Reform Law, 33 BNA PENSION \& BENEFITS REP. 2315, 2317 (2006), (stating "a number of courts have interpreted the use of a cafeteria plan to be an employer "endorsement").

135. Egelhoff v. Egelhoff, 532 U.S. 141, 147 (2001) (internal quotation and citation omitted).

136. Id. at 147 (quoting Cal. Div. of Labor Standards Enforcement, 519 U.S. at 325). 
Again, our starting point is that a primary purpose of ERISA was to allow for nationally uniform administration of employee benefit plans. As stated above, a premium-only cafeteria plan is not by itself an ERISA plan. However, the FRS might be interpreted as requiring employers who currently sponsor an ERISA health plan to adopt a specific funding mechanism for the plan-a cafeteria plan. If characterized as a law that mandates the funding mechanism for ERISA plans, the law would be preempted as interfering with benefit plan administration, in clear conflict with ERISA's goals. ${ }^{137}$ Even where an employer offers an ERISA plan, however, the FRS requirement to offer employees a premium-only cafeteria plan need not involve the ERISA plan. That is, the employer could leave the ERISA plan as is (with whatever funding mechanism it currently uses) and offer employees a premium-only cafeteria plan that allows employees to pay health insurance premiums under a policy that does not qualify as an ERISA plan. ${ }^{138}$ Similarly, for employers that do not offer an ERISA plan, the cafeteria plan requirement can be met by adopting such a plan in conjunction with health insurance not governed by ERISA. ${ }^{139}$ Because of this ability to meet the cafeteria plan requirement without involving an ERISA plan, nationally uniform benefit administration is not disrupted. As a result, the FRS should not be preempted by ERISA.

\section{POTENTIAL LESSONS FROM MASSACHUSETTS}

If this Article is correct, and both Massachusetts pay or play laws survive preemption, what will they contribute to health care reform? What lessons can other states take away from the Massachusetts employer provisions? This section briefly examines these questions.

137. For example, if the law stated that any employer who sponsors a health plan must adopt a cafeteria plan as the funding mechanism for the plan, the law would be clearly preempted as mandating an employee benefit plan structure.

138. It is unlikely that an employer would make such a choice, as it would be easier for an employer to simply offer the premium-only cafeteria plan in conjunction with its existing ERISA plan. However, nothing in the FRS mandates this result. Nor is the result effectively forced by the structure of the FRS. The choice of how to meet the FRS requirement is a real one.

139. For employers that qualify, the simplest action to take would be to adopt a cafeteria plan to allow their employees to purchase any health insurance available through the Connector. The Connector is a newly-created state agency that will provide a central clearinghouse for individuals and small employers to shop for health insurance. See Mass. Plan, supra note 6, $\S 101$ (defining and describing the role of the Connector). Any individual, other than an individual who is employed by an employer with more than fifty employees and is offered subsidized health insurance from such employer, is eligible to purchase insurance through the Connector. Id. (defining "eligible individuals"). The Connector specifically allows for the pre-tax payment of premiums through a cafeteria plan. Id. $\S 32$. 


\section{A. The Impact of the Fair Share Contribution}

As previously discussed, the FSC has a weak penalty for noncompliance-a per-worker fee of no more than $\$ 295$ per year. The revenue resulting from the fee is expected to be a relatively modest $\$ 26$ million. ${ }^{140}$ This fee equals approximately $3 \%$ of the amount that Massachusetts currently spends on uncompensated care. ${ }^{141}$ While the revenue gained from the FSC will have a modestly positive effect on health care in the state, the more interesting issue is the effect the FSC will have on an employer's decision to offer health care coverage to employees.

Before discussing the FSC's impact on employer decision-making, it is helpful to briefly review existing data on employer-provided health insurance. As in the rest of the country, the majority of Massachusetts residents are covered by employer-provided health insurance. ${ }^{142}$ Nearly all large employers offer employee health insurance, but the propensity to offer coverage corresponds to employer size. ${ }^{143}$ As a result, to make significant gains in employer-provided coverage, reform efforts must target small employers.

The FSC applies to all but the very smallest employers, and therefore picks up at least a good part of the "target" population. ${ }^{144}$ However, given the small size of the penalty associated with non-compliance, it is unlikely that employers will change their behavior to avoid it (indeed, this is part of the argument for avoiding ERISA preemption). ${ }^{145}$

140. Massachusetts Proposes Minimum Standard for Employer-Based Care Under New Law, BNA HEALTH CARE DAILY REP., July 5, 2006.

141. Figure calculated by author using annual uncompensated care expenses provided in the editorial Beyond the Health Pool, BosTON GloBE, Feb. 15, 2006, at A18. The amount the state spends on uncompensated care is expected to decrease as various health reforms, such as the individual mandate, become effective. See PRESENTATION to THE JONNT CAUCUS fOR House MEMBERS, supra note 6, at 9 (noting that the SNC office developed a standard fee schedule to reimburse uncompensated care).

142. THE Office OF Health \& Human SeRvs., MassachusetTs EMPloyer Health INSURANCE SURVEY 2 (2005), http://www.mass.gov/Eeohhs2/docs/dhcfp/r/survey/er_2005_comp_ results.pdf [hereinafter MASS. EMPLOYER SURVEY] (finding that $63 \%$ of all residents are covered by employer policies).

143. See id. at 5 (finding that $68 \%$ of employers with two to fifty employees offer health insurance, while $97 \%$ of employers with fifty-one or more employees offer such coverage).

144. However, the very smallest employers are the least likely to offer health insurance coverage. See id. at 5 (finding that $60 \%$ of employers with two to nine employees offered health insurance coverage, compared with $88 \%$ of employers with ten to twenty-four employees).

145. Despite its small size, the fee may be sufficient to change employer behavior where the difference between the value employees place on the benefit and the benefit employers expect to receive from offering such coverage is less than $\$ 295$. 
Nevertheless, even if the fee itself is insufficient to alter behavior, the FSC may have signaling effects on employer decision-making. ${ }^{146}$

One possibility is that the law will signal to employers that they have a responsibility to make a "fair and reasonable" contribution to employee health coverage. ${ }^{147}$ In that case, employers might change their behavior even though the fee itself is not sufficient to force such a decision. Another possibility (and one that is perhaps more likely) is that the design of the FSC will signal to the employer that making a "fair and reasonable" contribution to employee health coverage and paying $\$ 295$ per employee per year are normative equivalents. If this is true, we might actually see some employers drop coverage, as the $\$ 295$ fee is in almost all cases less expensive than making a "fair and reasonable" contribution to employee health coverage. This outcome is unlikely for employers who currently offer coverage, because such employers presumably made a rational decision that it was beneficial to their business to offer employees health coverage. However, this signaling effect may cause new employers to be less likely to offer coverage in the first place, all other things being equal. That is, they may receive the signal that paying a $\$ 295$ per employee fee is doing their "fair share" with respect to employee health care.

It is simply too early to tell what signaling effect the FSC will have on employer decision-making. Other states may be tempted to enact weak pay or play laws similar to the FSC, because they can withstand ERISA preemption. Because of the small revenue gains and potentially negative signaling effects, such states may want to wait until data is available from Massachusetts before proceeding.

\section{B. The Impact of the Free Rider Surcharge}

In its health care reform, Massachusetts attempted to address a fundamental problem in health care: employees are only able to pay health insurance premiums on a pre-tax basis if coverage is purchased through their employer. To further complicate the situation, this favorable tax treatment is only available if the employer sponsors a cafeteria plan. $^{148}$ Massachusetts's FRS attempts to require all but the

146. For more on law's signaling effects, see, e.g., Eric A. Posner, Law, Economics, and Inefficient Norms, 144 U. PA. L. REV. 1697 (1996); Richard H. Pildes, The Unintended Cultural Consequences of Public Policy: A Comment on the Symposium, 89 MiCH. L. REV. 936 (1991); Lawrence Lessig, The Regulation of Social Meaning, 62 U. CHI. L. REV. 943 (1995).

147. See supra Part IV (discussing fair share contribution).

148. In 2005 , only $49 \%$ of Massachusetts employers reported that they offered a cafeteria plan to permit the pre-tax payment of health insurance premiums. MASS. EMPLOYER SURVEY, supra note 
smallest employers to adopt premium-only cafeteria plans so that, even if the employer does not sponsor an ERISA health plan, the individual can pay for health insurance on a pre-tax basis, cutting the cost of such coverage by as much as $42 \%$. ${ }^{149}$

Assuming the FRS survives ERISA preemption, Massachusetts will have succeeded in requiring employers to allow their employees to take advantage of existing federal tax benefits that are available only for employer-provided health insurance, and coverage rates should increase as a result. ${ }^{150}$ The effect on coverage will likely be greater than that which results from the FSC, because of its direct impact on the affordability of health insurance.

While the FRS cafeteria plan requirement is likely to increase health insurance coverage rates, the costs it imposes on employers should not be ignored. First, the employer must adopt a written cafeteria plan document that complies with certain tax code requirements. ${ }^{151}$ The IRS does not publish a standard or form cafeteria plan document that employers can adopt. As a result, employers will have to pay a third party to provide a cafeteria plan document. In addition, cafeteria plans must comply with detailed "qualified change of status" rules. These rules govern the circumstances under which a participant in a cafeteria plan can change his or her annual elections under the plan, and what types of mid-year changes are permissible. ${ }^{152}$ Policing these rules requires an employer either to have an in-house expert who is familiar with the regulations and can implement them, or to outsource the

142 , at 20 .

149. See supra Part V (discussing the cafeteria plan and the free rider surcharge). A $42 \%$ savings would result for an individual in the top marginal tax bracket $(35 \%)$, taking into account the additional savings of avoiding payroll taxes (7.65\%). A 2002 survey found that many small employers are unaware of the tax advantages associated with employer-provided insurance. Paul Fronstin et al., Issue Brief No. 253: Small Employers and Health Benefits: Findings From the 2002 Small Employer Health Benefits Survey, EMP. BENEFIT RES. INST., Jan. 2003, at 16-17, http:// www.ebri.org/pdf/briefspdf/0103ib.pdf.

150. On its own, the cost savings may be insufficient to significantly affect the percentage of individuals who elect employer-provided coverage. See Michael Chernew et al., The Demand for Health Insurance Coverage by Low-Income Workers: Can Reduced Premiums Achieve Full Coverage?, 32 HEALTH SERVS. RES. 453, 453 (1997), available at http://www.pubmedcentral.nih. gov/articlerender.fcgi?artid $=1070205$. In a study of low-income workers at small firms with no other source of health insurance coverage, premium subsidies of $75 \%$ only increased participation rates from $89 \%$ to $92.6 \%$. Id . at 464 . The authors note, "[a]lthough the overwhelming majority of individuals participate in their employer's plan, there appears to be a subset who do not, even at prices heavily distorted by the employer. For this group of workers, it is unlikely that a further subsidy would alter participation dramatically." Id. This calculus might change with the addition of the individual mandate, see infra Part IV.C.

151. See I.R.C. $\$ 125$ (2000).

152. See Treas. Reg. $\S 1.125-4$ (2007) (discussing permitted election changes). 
administration of the cafeteria plan. ${ }^{153}$ Most large employers already utilize cafeteria plans and therefore would not face any increased costs as a result of the FRS. ${ }^{154}$ Small employers, however, may face significantly increased costs. ${ }^{155}$ Standard economic theory would predict that these increased costs will be passed along to workers in the form of lower wages. What is unknown at this point is whether the tax savings associated with a cafeteria plan will more than offset any decrease in wages. If so, the FRS should have a positive net impact on health care coverage rates in Massachusetts.

Massachusetts could lower employer costs by providing a standard premium-only cafeteria plan document that employers could adopt. ${ }^{156}$ It could also provide educational materials regarding permissible mid-year election changes and other legal requirements related to cafeteria plans. Other states that are contemplating a cafeteria plan requirement should give serious consideration to providing a standard cafeteria plan document, as well as educational materials, as doing so should lower employer costs and protect employee wages.

\section{Was Governor Romney Right?}

When Governor Mitt Romney vetoed the employer provisions of the Massachusetts health care reform legislation, he stated simply that such provisions were not necessary to achieve health care reform. ${ }^{157}$ The implication is that the individual mandate and market reforms contained in the legislation would be sufficient to increase coverage rates.

While employers currently provide health insurance to $63 \%$ of Massachusetts's population, ${ }^{158}$ some employees who are offered

153. Alternatively, the employer could forbid any mid-year election changes. However, such a restriction might have a negative effect on health insurance enrollment.

154. In $2005,80 \%$ of Massachusetts employers with more than fifty employees provided for the pre-tax payment of health insurance premiums through a cafeteria plan. MASS. EMPLOYER SURVEY, supra note 142 , at 21 .

155. In 2005, 45\% of Massachusetts employers with two to fifty employees sponsored a cafeteria plan for the pre-tax payment of health insurance premiums. $I d$.

156. Employers would still need to be advised to seek independent legal counsel to review the plan, unless the State also provided a legal opinion that the standard plan met all requirements under $\S 125$.

157. Letter from Mitt Romney, Governor of Mass., to Mass. Senate and House of Representatives (Apr. 12, 2006), available at http:/www.ncsl.org/print/health/vetoletter.pdf.

158. MASS. EMPLOYER SURVEY, supra note 142, at 2. Of non-elderly residents with health insurance, $83 \%$ receive coverage through an employer. MASS. DIV. OF HEALTH CARE FIN. \& POLICY, HEALTH INSURANCE STATUS OF MASSACHUSETTS RESIDENTS 3 (5th ed. 2006) [hereinafter INS. STATUS OF MASS. RESIDENTS] 
coverage from employers fail to elect such coverage, ${ }^{159}$ and some employers simply do not offer coverage. Employees who decline employer-offered coverage most commonly cite cost as the primary factor in their decision. ${ }^{160}$ Small employers are the most likely to fail to offer health insurance to their employees, and those employers similarly cite affordability as a major factor in their decision to not offer a plan. ${ }^{161}$ Twenty-eight percent of small employers who do not offer health insurance also cite a lack of employee demand for the benefit as a major factor in the decision to not offer coverage. ${ }^{162}$

Given this data, it is possible that the combination of an individual coverage mandate and individual and small market reforms might, by themselves, result in a greater number of employers health coverage and a greater number of individuals accepting employer-offered coverage. For one, we would expect an individual coverage mandate to increase employee demand for health care coverage. Data suggest that this might have at least some positive effect on employer-offer rates. Forty-five percent of small employers surveyed reported that they would be either much more likely or somewhat more likely to consider offering a health plan if employees asked for it. ${ }^{163}$ In addition, small group market reforms might lower costs for small businesses, which should also increase the likelihood of employers offering coverage. ${ }^{164}$ In turn, the individual mandate should make employees more likely to enroll in

159. A survey of Massachusetts residents found that $78 \%$ of employees who are eligible for employer coverage choose to enroll. MASS. EMPLOYER SURVEY, supra note 142, at 44.

160. Paul Fronstin, Issue Brief No. 287, Sources of Health Insurance and Characteristics of the Uninsured: Analysis of the March 2005 Current Population Survey, EMP. BENEFITS RES. INST., Nov. 2005, at 1, 15, fig. 15 available at http://www.ebri.org/pdf/EBRI_IB_11-2005.pdf; see also INS. STATUS OF MASS. RESIDENTS, supra note 158, at 12, 13 (reporting 2006 survey findings that $67 \%$ of Massachusetts working uninsured adults reported that insurance being "too expensive" was why they declined employer-offered coverage).

161. See Fronstin, supra note 149 , at 1, 14 (stating that $63 \%$ of small employers surveyed reported "the business cannot afford it" as a major factor in the decision to not offer a health plan); see also MASS. EMPLOYER SURVEY, supra note 142, at 53 (reporting that in 2005, 85\% of Massachusetts employers cited "premiums too high" as a reason for not offering coverage).

162. Fronstin, supra note 149, at 14; see also MASS. EMPLOYER SURVEY, supra note 142, at 53 (reporting that in 2005, $40 \%$ of Massachusetts employers cited "employees prefer higher pay" as a reason for not offering coverage)

163. Fronstin, supra note 149 , at 15 . Among small employers, $14 \%$ reported that they were "much more likely" and $31 \%$ reported that they were "somewhat more likely" to consider offering a health plan. Id.

164. Employers would need knowledge of market reforms in order for such reforms to influence employer decisions to offer health coverage. At least one survey has suggested that small employers are not generally aware of the small group market reforms that passed in the 1990s. Id. at 19 . 
health coverage, as the cost of declining coverage is raised by the penalties associated with the individual mandate. ${ }^{165}$

Even without the FSC and FRS, the individual mandate and individual and small group market reforms should increase demand for employer coverage and thereby help to address a market failure. The combination of these reforms will hopefully allow the market to function more effectively than it has-making a market-based health care system viable and lessening the need for, and attractiveness of, a single payor system. This type of health care reform is likely to be more palatable to a greater number of Americans, as it addresses problems within the existing system, rather than moving to a government-based system.

\section{CONCLUSION}

The broad preemption of state laws by ERISA means options to involve employers in health care reform are limited, at best. In the end, the comprehensive approach taken by Massachusetts may represent the best way forward. Massachusetts has required individuals to purchase health insurance if an affordable policy is available to them. It has simultaneously tried to remove market impediments and encourage employers to be actively involved in employee health coverage.

While we will not know for some time how successful Massachusetts will be, we should be thankful that Massachusetts has embarked on this bold health care experiment. They have enacted reforms that include individuals, the state, employers, and the market. For the first time, we will get to see whether weak pay or play laws survive ERISA preemption and the extent to which such pay or play laws impact employer-provided coverage. We should also be able to evaluate whether an individual mandate can create enough employee demand so that employers will be persuaded to provide health coverage to their employees and greater numbers of employees will be persuaded to accept such offers of coverage. If cafeteria plan requirements survive, we will be able to gauge the extent to which the tax exemption for employerprovided health care is critical in making health insurance affordable and increasing coverage rates. Clarifying the contours of ERISA preemption

165. In 2007, an individual who fails to purchase health insurance when an affordable policy is available to her will lose her personal tax exemption. Mass. Plan, supra note $6, \S 12$. The exemption is currently a deduction of $\$ 3850$ from taxable income. MASS. GEN. LAWS ANN. Ch. 62 , $\S 3 \mathrm{~B}(\mathrm{~b})(1)(\mathrm{A})$ (West Supp. 2006). Given Massachusetts's 5.3\% individual income tax rate, the net effect would be an approximate $\$ 200$ annual penalty. In 2008 and thereafter, the penalty will be equal to $50 \%$ of the cost of the applicable health insurance premium. Mass. Plan, supra note $6, \S 13$. 
as it applies to pay or play laws, and the data that becomes available as Massachusetts implements its bold plan, will be of great significance in structuring future health care reform efforts. 